Karno Ariyanto: Implementasi Sistem Penataan Arsip ... 


\title{
IMPLEMENTASI SISTEM PENATAAN ARSIP DI MADRASAH ALIYAH NEGERI 1 PEKANBARU
}

\author{
Karno Ariyanto \\ UIN Sulthan Syarif Kasim Pekanbaru Riau, Indonesia \\ ari_natuna88@yahoo.co.id
}

\begin{abstract}
The aim of this study is to investigate the archives management in Madrasah Aliyah Negeri 1 Pekanbaru and to identify its obstacle and supporting factors. The participants of this research were administrator and the vice headmaster. Techniques of collecting data were interviewed, observation and documentation. Analysis of the data used Miles and Huberman model, namely data reduction, data model, and verification of conclusions. This research revealed that: this school has implemented the archives storage using the subject filling system, there was no recorded system for borrowing archives, the staffs has checked the borrowed and returned archives, the finding of the archives used manual system, this school has conducted the maintenance and security of records, the staffs has removed the archives periodically. The obstacle factors were the educational background of head of administration staffs was D3 (Diploma Degree) of Secretary in Bunda Persada Academy, and administration staffs were high school graduate. Supporting factors were infrastructures were sufficient, there was supervision by the headmaster and there was good communication and cooperation between the headmaster and administration staff.
\end{abstract}

Keywords: Archives Management, Subject Filling System, Maintenance

\begin{abstract}
ABSTRAK
Tujuan Penelitian ini adalah untuk menginvestigasi penataan arsip di Madrasah Aliyah Negeri 1 Pekanbaru dan untuk mengidentifikasi faktor penghambat dan pendukung. Peserta dalam penelitian ini adalah staff administrasi dan wakil kepala madrasah. Teknik pengumpulan data yang digunakan wawancara, observasi dan dokumentasi. Analisis data menggunakan model Miles dan Huberman yakni: reduksi data, model data, dan verifikasi kesimpulan. Penelitian ini menemukan bahwa sekolah ini telah mengimplementasikan penyimpangan arsip menggunkana sistem subjek, tidak ada sistem pencatatan untuk peminjaman arsip, pegawai telah mengecek peminjaman dan pengembalian arsip, pencarian arsip menggunakan sistem manual, sekolah tersebut telah melaksanakan pemeliharan dan pengamanan arsip, pegawai telah memusnahkan arsip secara berkala. Faktor penghambat penataan arsip disekolah ini adalah latarbelakang kepala tata usaha yang D3 sekretaris di Akademi Bunda Persada, dan pegawai yakni SMA. Adapun factor pendukung adalah infrastruktur yang cukup memadai, adanya pengawasan dari kepala
\end{abstract}


madrasah, dan adanya komunikasi dan kerjasama yang baik antara kepala madrasah dan staf administrasi.

\section{Kata kunci: Penataan Arsip, Sistem Aubjek, dan Pemeliharaan Arsip}

\section{PENDAHULUAN}

Setiap lembaga pendidikan mempunyai unit atau bagian yang mengelola segala sesuatu yang berhubungan dengan kegiatan administrasi lembaga pendidikan tersebut yaitu bagian Tata Usaha. Dalam manajemen pendidikan pegawai tata usaha merupakan salah satu komponen dari manajemen pendidikan yaitu tenaga kependidikan sekolah/madrasah. Salah satu kegaitan pengelolaan yang dilakukan oleh bagian tata usaha ini adalah mengelola surat masuk dan surat keluar yang pada akhirnya berhubungan dengan kegiatan kearsipan.

Pengelolaan dalam Al-Qur'an erat kaitannya dengan kata altadbir (pengaturan). Kata al-tadbir berasal dari kata dabbara

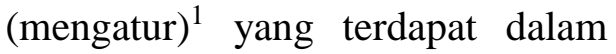
Al-Qur'an, seperti firman Allah SWT:

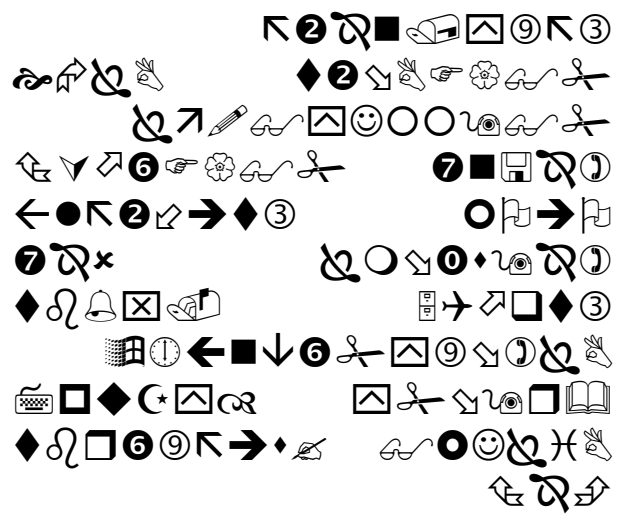

"Dia mengatur urusan dari langit ke bumi, kemudian (urusan) itu naik kepadanya dalam satu hari

1 U. Saefullah, Manajemen Pendidikan Islam, (Bandung: CV. Pustaka Setia), 2012, h. 1 yang kadarnya adalah seribu tahun menurut perhitunganmu”. (Q.S. As-Sajdah: 5). ${ }^{2}$

Dari ayat di atas dapat diketahui bahwa Allah SWT merupakan pengatur alam. Akan tetapi, sebagai tenaga administrasi yang mengurusi kegiatan kearsipan, maka arsiparis harus mengatur, mengelola dan menata arsip sebaikbaiknya sebagaimana Allah SWT mengatur alam raya ini.

Kearsipan adalah suatu proses kegiatan mulai dari penerimaan, pengumpulan, pengaturan, pemeliharaan dan penyimpanan warkat menurut sistem tertentu, sehingga saat diperlukan dapat ditemukan dengan cepat dan mudah. ${ }^{3}$ Sedangkan arsip adalah setiap catatan (record/warkat) yang tertulis, tercetak, atau ketikan dalam bentuk huruf, angka, gambar yang mempunyai arti atau tujuan sebagai bahan komunikasi dan informasi yang terekam pada kertas, kertas film, media komputer, dan lain-lain yang disimpan menurut suatu aturan sehingga apabila diperlukan dapat ditemukan dengan mudah. ${ }^{4}$

Suatu lembaga pendidikan juga membutuhkan bantuan data

2 Departemen Agama Republik Indonesia, Al-Qur'an dan Terjemahan, (Jakarta: Indiva), 2009, h. 415

${ }^{3}$ Sri Endang R, dkk, Modul Mengelola dan Menjaga Sistem Kearsipan: Bidang Keahlian Bisnis dan Manajemen (Program Keahlian Administrasi Perkantoran) untuk SMK dan MAK, (Jakarta: Erlangga), 2009, h. 11

${ }^{4}$ Ibid, h. 8 
dan informasi untuk menyelesaikan pekerjaan dan mengefektifkan manajemennya untuk dapat mencapai tujuan-tujuan dengan baik. Salah satu cara yang dilakukan oleh lembaga pendidikan dalam menghadapi perkembangan teknologi adalah dengan memiliki suatu sistem informasi yang cukup baik, cepat dan teliti. Nilai informasi ditentukan oleh lima karakteristiknya, yaitu ketelitian, ketepatan waktu, kelengkapan, keringkasan dan kesesuaian, karena dengan hal ini akan membantu kelancaran pelaksanaan kegiatan lembaga pendidikan. ${ }^{5}$ Untuk mewujudkan hal ini maka arsip sangat berperan penting dalam sebuah lembaga pendidikan.

Pada lembaga pendidikan arsip berperan sebagai pusat ingatan, sumber informasi, dan sebagai alat pengawasan, yang sangat diperlukan dalam rangka kegiatan perencanaan, pengembangan, perumusan kebijakan, pengambilan keputusan, pembuatan laporan pertanggungjawaban, penilaian dan pengendalian setepat-tepatnya. ${ }^{6}$

Sistem pengelolaan arsip meliputi berbagai kegiatan mengklsasifikasi surat, memberi kode, menyimpan surat, memelihara secara tepat sampai mengenai cara penyingkiran dan pemusnahan surat yang sudah tidak dipergunakan lagi. ${ }^{7}$

5 Hayatur Rahmi, Pengelolaan Arsip Dinamis Aktif di Badan Kepegawaian Daerah Provinsi Jawa Barat, Vo. 1, No. 1, (eJurnal Mahasiswa Universitas Padjadjaran), 2012.

${ }^{6}$ Basir Barthos, Manajemen Kearsipan untuk Lembaga Negara, Swasta dan Perguruan Tinggi, (Jakarta: Bumi Aksara), 2009, h. 2

${ }^{7}$ Ibnu Syamsi (a), Sistem dan Prosedur Kerja, (Jakarta: Bumi Aksara), 1994, h. 8
Demikian pentingnya arsip, oleh karena itu perlu dilakukan dengan prosedur yang baik dan benar di dalam pengelolaan arsip, untuk menjaga daur hidup arsip itu sendiri mulai dari tahap penciptaan, penggunaan, pemeliharaan dan pemindahan serta pemusnahannya. Di dalam pekerjaan menyimpan arsip tidak hanya menyimpan saja, tetapi menyangkut penempatan dan penemuan kembali. Penataan arsip dikatakan baik apabila pada saat diperlukan dapat ditemukan dengan mudah, cepat dan tepat.

Apabila arsip yang dimiliki oleh sebuah lembaga pendidikan kurang baik pengelolaannya, dapat mengakibatkan sulitnya menemukan informasi yang telah disimpan dan akhirnya dapat menghambat tahapan proses pekerjaan selanjutnya. Mengingat peran arsip sangat penting, maka sebaiknya arsip dikelola menggunakan sistem pengelolaan arsip yang baik dan benar. Sistem pengelolaan arsip dapat dikatakan baik dan benar apabila pada waktu arsip tersebut diperlukan dapat ditemukan kembali dengan cepat dan tepat.

Badri Munir Sukoco mengemukakan bahwa tujuan dari pengelolaan arsip adalah:

1. Unuk menjaga dokumen maupun arsip agar dapat diakses dan digunakan sepanjang ada nilai kegunaannya.

2. Untuk membuat informasi dari dokumen dan arsip, tersedia dalam format yang tepat, digunakan oleh orang yang 
tepat, dan digunakan pada saat yang tepat. ${ }^{8}$

Arsip tersebut merupakan bukti pertanggungjawaban kegiatan, oleh karena itu perlu diadakan penataan secara baik dan benar. Sehingga tidak terjadi penumpukan arsip yang dapat menghambat kegiatan administrasi dan tugas kedinasan. Penumpukan arsip itu terjadi karena disebabkan oleh beberapa faktor seperti kurangnya jumlah sumber daya manusia yang menangani bidang kearsipan, kurangnya perhatian atau atensi dari pimpinan, kurangnya dana yang dianggarkan untuk bidang kearsipan dan kurangnya peralatan yang menunjang dalam bidang kearsipan.

\section{KERANGKA TEORITIS}

\begin{abstract}
Undang-Undang Republik Indonesia Nomor 43 Tahun 2009 Pasal (1) arsip adalah rekaman kegiatan atau peristiwa dalam berbagai bentuk media sesuai dengan perkembangan teknologi informasi dan komunikasi yang dibuat dan diterima oleh lembaga Negara, pemerintah daerah, lembaga pendidikan, perusahaan, organisasi politik, organisasi kemasyarakatan, dan perseorangan dalam pelaksanaan kehidupan bermasyarakat, berbangsa dan bernegara. $^{9}$

Arsip adalah suatu kumpulan dokumen yang disimpan secara sistematis karena mempunyai suatu kegunaan agar setiap kali diperlukan dapat secara cepat
\end{abstract}

8 Badri Munir Sukoco, Administrasi Perkantoran Modern, (Surabaya: Erlangga), 2007, h. 82

${ }^{9}$ Undang-Undang RI Nomor 43 Tahun 2009, Tentang Kearsipan, h. 3 ditemukan kembali. ${ }^{10}$ Zulkifli Amsyah menyatakan arsip adalah setiap catatan yang tertulis, tercetak atau ketikan, dalam bentuk huruf, angka atau gambar, yang mempunyai arti atau tujuan tertentu sebagai bahan komunikasi informasi, yang terekam pada kertas (kartu, formulir), kertas film (slide, film-strip, mikro film), media komputer (pita tape, piringan, rekaman, disket), kertas photo copy dan lain-lain. ${ }^{11}$

Berdasarkan pendapat beberapa ahli di atas, maka dapat disimpulkan bahwa arsip adalah rekaman yang dibuat dan diterima oleh setiap lembaga atau organisasi baik kelompok maupun perseorangan, lembaga pemerintahan maupun swasta. Kemudian arsip juga dapat diartikan sebagai dokumen yang berupa catatan pada kertas, rekaman suara, video yang mempunyai nilai guna tertentu yang disimpan secara sistematis baik secara manual maupun elektronik sehingga pada saat diperlukan dapat ditemukan dengan mudah, tepat, dan cepat.

1. Guna Arsip Arsip mempunyai peranan yang sangat penting bagi sebuah kantor, maka keberadaan arsip perlu mendapatkan perhatian khusus sehingga keberadaan arsip pada sebuah kantor benar-benar menunjukkan peran yang sesuai dan dapat mendukung penyelesaian pekerjaan yang

${ }^{10}$ Agus Sugiarto dan Teguh Wahyono, Manajemen Kearsipan Modern, (Yogyakarta: Gava Media), 2005, h. 4

11 Zulkifli Amsyah, Manajemen Kearsipan, Cet. Ke-9 (Jakarta: PT. Gramedia Pustaka Utama), 2001, h. 3 
dilakukan semua personil dalam kantor tersebut.

ada beberapa kegunaan arsip yaitu, a) arsip sebagai sumber ingatan atau memori, b) arsip sebagai bahan pengambil keputusan, c) arsip sebagai bukti legalitas, dan d) arsip sebagai rujukan historis. Namun demikian, tidak semua arsip mempunyai kegunaan yang sama, setiap arsip punya kegunaan yang berbeda-beda. Guna lain dari arsip adalah sebagai alat ukur kegiatan organisasi dan sebagai sumber ilmu pengetahuan.

2. Jenis Arsip

Arsip sebagai dokumen yang memiliki peran dan keguanaan yang berbeda dalam sebuah organisasi, juga mempunyai jenis yang berbeda pula. Sri Endang $\mathrm{R}$ mengemukakan bahwa ada lima jenis arsip, yaitu: ${ }^{12}$

a. Arsip berdasarkan bentuk fisiknya, dibagi atas:

1) Arsip yang berbnetuk lembaran. Contoh: surat, kuitansi, faktur dan foto

2) Arsip yang tidak berbentuk lembaran. Contoh: disket, flash disk, mirko film, dan rekaman pada pita kaset.

b. Jenis arsip berdasarkan masalahnya, terbagi atas:

1) Financial record, yaitu arsip-arsip yang berisi catatan-catatan mengenai masalah keuangan.

Contoh: kuitansi, giro, cek dan kartu kredit.

2) Inventory record, yaitu arsip-arsip yang berhubungan dengan masalah inventaris. Contoh: catatan tentang jumlah barang, merek, ukuran, dan harga.

3) Personal record, yaitu arsip-arsip yang berhubungan dengan kepegawaian. Contoh: surat lamaran kerja, curriculum vitae, absensi pegawai, dan surat keputusan.

4) Sales record, yaitu arsiparsip yang berhubungan dengan masalah penjualan. Contoh: data penjualan dan daftar nama agen dan distributor.

5) Production record, yaitu arsip-arsip yang berhubungan dengan masalah produksi. Contoh: arsip tentang jenis bahan baku, jenis alat/mesin yang digunakan, dan jenis kualitas barang.

c. Jenis arsip berdasarkan pemiliknya, dibagi atas:

1) Lembaga pemerintahan

a) Arsip nasional di Indonesia (Arsip Nasional Republik Indonesia)

b) Arsip nasional di setiap ibu kota Daerah Tingkat I (arsip Nasional Daerah)

2) Instansi Pemerintah/swasta

a) Arsip primer dan arsip skunder. Arsip primer adalah arsip aslinya, sedangkan arsip skunder adalah arsip

\footnotetext{
${ }^{12}$ Sri Endang R, dkk, Op.Cit, h. 9-10
} 
yang berupa tindasan atau karbon kopi,

b) Arsip sentral dan arsip unit. Arsip sentral adalah arsip yang disimpan pada pusat arsip atau arsip yang dipusatkan penyimpanannya.

Arsip unit adalah arsip yang disebarkan penyimpanannya pada setiap bagian organisasi.

d. Jenis arsip berdasarkan sifatnya, dibagi atas:

1) Arsip tidak penting, yaitu arsip yang hanya mempunyai kegunaan informasi. Contoh: surat undangan dan surat pemberitahuan.

2) Arsip biasa, yaitu yang semula penting, akhirnya tidak berguna lagi pada saat arsip yang diinformasikan itu berlalu. Contoh: surat lamaran kerja dan tagihan.

3) Arsip penting, yaitu arsip yang ada hubungannya dengan masa lalu dan masa yang akan datang, sehingga perlu disimpan dalam waktu yang lama. Contoh: surat perjanjian dan kontrak.

4) Arsip sangat penting (vital), yaitu arsip yang dapat dijadikan alat pengingat selamalamanya. Contoh: naskah proklamasi dan surat keputusan hasil penelitian ilmiah.

5) Arsip rahasia, yaitu arsip yang isinya hanya boleh diketahui oleh orang tertentu dalam suatu organisasi. Contoh: hasil penilaian pegawai dan strategi pemasaran.

e. Jenis arsip berdasarkan fungsinya, dibagi atas:

1) Arsip dinamis, yaitu arsip yang digunakan secara langsung dalam perencanaan, penyelenggaraan kehidupan kebangsaan pada umumnya, atau dipergunakan secara langsung dalam penyelenggaraan administrasi Negara. Arsip dinamis dibedakan sebagai berikut:

a) Arsip aktif, yaitu arsip yang dipergunakan secara terus menerus dalam kegiatan kantor,

b) Arsip semi aktif, yaitu arsip yang frekuensi

penggunaannya sudah menurun, tetapi kadangkadang masih diperlukan,

c) Arsip inaktif, yaitu arsip dinamis yang sudah sangat jarang digunakan,

2) Arsip statis, yaitu arsip yang tidak digunakan secara langsung dalam perencanaan, penyelenggaraan kehidupan kebangsaan pada umumnya, atau dipergunakan secara langsung dalam penyelenggaraan administrasi Negara. 
3. Penataan Arsip

Penataan arsip adalah proses pengklasifikasian dan mengatur arsip dalam suatu tatanan yang sistematis dan logis, serta menyimpannya dalam tempat yang aman agar arsip tersebut dapat secara cepat ditemukan saat diperlukan. ${ }^{13}$

Jadi yang dimaksud dengan penataan arsip adalah cara untuk mengatur dan menata arsip dalam suatu susunan yang sistematis dimulai dari mengklasifikasi surat, memberi kode, menyimpan, menemukan kembali arsip sampai dengan pemusnahan atau penyingkiran arsip yang sudah diperlukan lagi dengan memperhatikan bentuk, kegunaan dan sifat arsip yang bertujuan menunjang kelancaran pelaksanaan tugas organisasi.

a. Penyimpanan arsip

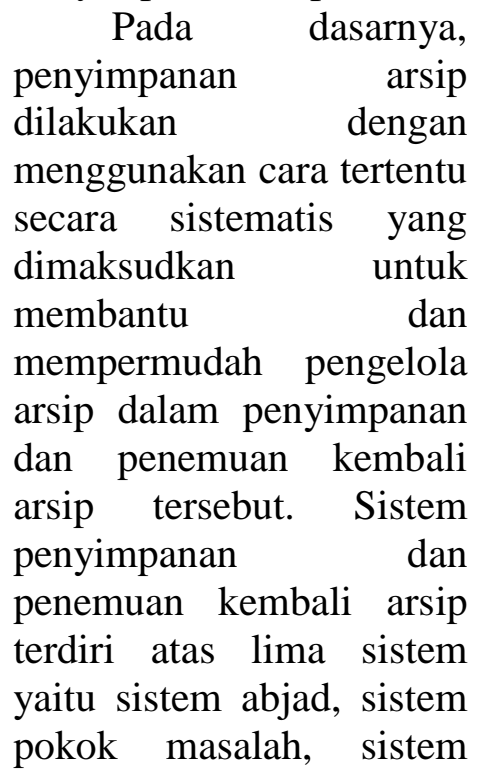

13 Durotul Yatimah, Pengembangan Sumber Daya Manusia: Kesekretariatan Modern dan Administrasi Perkantoran, (Bandung: Pustaka Setia), 2009, h. 184 nomor, sistem tanggal, dan sistem wilayah.

1) Sistem Abjad

(Alphabetical Filling System)

Sistem abjad

adalah sistem

penerimaan,

penyusunan,

penyimpanan,

penggunaan,

pemeliharaan dan

penemuan kembali

surat/warkat dengan

menggunakan

petunjuk abjad. ${ }^{14}$

Dalam

penyusunannya setiap map (folder)

menunjukkan nama

korespondennya serta

disusun berdasarkan

abjad. Sistem abjad ini

merupakan sistem

penyimpanan yang

sederhana dan mudah

dalam menentukan

dokumen, dimana

petugas bisa langsung

ke file penyimpanan

dan melihat huruf

abjad, tanpa melalui

alat bantu seperti

indeks yang disebut

juga dengan sistem

arsip langsung (direct

filing system).

2) Sistem

Masalah/Perihal/Poko

k Soal (Subject Filling System)

Sistem masalah adalah salah satu
14 Edy Roesdiono (a), Mengelola Dokumen dengan Sistem Abjad, (Pekanbaru: Direktorat Jenderal Pendidikan Dasar dan Menengah Departemen Pendikan Nasinoal), 2003 Op.Cit, h. 9 
sistem penyimpanan dokumen yang berdasarkan kepada isi dari dokumen itu. Isi dokumen sering disebut perihal, pokok masalah, permasalahan, pokok surat atau subjek. $^{15}$ Dalam sistem masalah, arsip yang akan disimpan dikelompokkan

berdasarkan pada isi permasalahan yang terdapat pada arsip tersebut.

3) Sistem Nomor (Numerical Filling System)

Sistem nomor adalah salah satu sistem penyimpanan dan penemuan kembali arsip yang disusun dengan menggunakan

kode/nomor. Sistem penyimpanan

berdasarkan nomor terdiri dari:
penyimpanan, berdasarkan nomor Dewey.
a) Sistem
b) Sistem penyimpanan, berdasarkan nomor seri urut.
c) Sistem penyimpanan, berdasarkan

15 Edy Roesdiono (b), Mengelola Dokumen dengan Sistem Pokok Masalah, (Pekanbaru: Direktorat Jenderal Pendidikan Dasar dan Menengah Departemen Pendikan Nasinoal), 2003, h. 9
4) Sistem

$$
\begin{aligned}
& \text { nomor } \\
& \text { digit. }{ }^{16}
\end{aligned}
$$

\section{Tanggal/Urutan}

Waktu (Chronological Filling Sytem)

$$
\begin{array}{lr}
\text { Sistem } & \begin{array}{r}
\text { tanggal } \\
\text { sistem }
\end{array} \\
\text { adalah } & \begin{array}{r}
\text { dan } \\
\text { penyimpanan } \\
\text { penemuan }
\end{array} \text { kembali } \\
\text { arsip berdasarkan } \\
\text { tanggal, bulan, } \\
\text { tahun. }{ }^{17} \text { Dalam sistem } \\
\text { ini yang dijadikan } \\
\text { kode penyimpanan } \\
\text { dan penemuan } \\
\text { kembali arsip adalah } \\
\text { tanggal, bulan atau } \\
\text { tahun pemubatan yang } \\
\text { tercantum dalam arsip } \\
\text { itu sendiri. } \\
\text { Sistem } \\
\text { Wilayah/Regional/Da } \\
\text { erah (Geographical } \\
\text { Filling System) }
\end{array}
$$

5) Sistem

$\begin{array}{lr}\text { Sistem } & \text { wilayah } \\ \text { adalah } & \text { sistem } \\ \text { penyimpanan } & \\ \text { dokumen, berkas, atau } \\ \text { arsip yang dijadikan } \\ \text { pedoman } & \text { dalam } \\ \text { menemukan } r \text { arsip } \\ \text { secara cepat dengan } \\ \text { berdasarkan wilayah } \\ \text { dari pengirim surat } \\ \text { atau wilayah yang } \\ \text { dkirim surat. }{ }^{18} \text { Jadi, } \\ \text { dalam penyimpanan }\end{array}$

${ }^{16}$ Sri Endang R, dkk, Op.Cit, h. 64

17 Edy Roesdiono, (c), Mengelola Dokumen dengan Sistem Tanggal, (Pekanbaru: Direktorat Jenderal Pendidikan Dasar dan Menengah Departemen Pendikan Nasinoal), 2004, h. 9

18 Edy Roesdiono (d), Mengelola Dokumen dengan Sistem Wilayah, (Pekanbaru: Direktorat Jenderal Pendidikan Dasar dan Menengah Departemen Pendidikan Nasional), 2004, h. 9 
arsip dengan menggunakan sistem wilayah yang menjadi kata kunci adalah nama wilayah.

Dari kelima sistem penyimpanan dan penemuan arsip yang telah dijelaskan di atas, sistem yang sering digunakan adalah sistem abjad dikarenakan sistem abjad yang menjadi kata kunci dalam penyimpanan adalah nama orang atau organisasi, dan nama orang dan organisasi inilah kata yang paling mudah diingat oleh seseorang. Jadi dalam penggunaan setiap sistem, seorang arsiparis harus mengetahui dan memahami kata kaunci dari setiap sistem yang digunakan, sehingga pada arsip diperlukan tidak memerlukan waktu yang lama untuk meenmukannya.

b. Peminjaman arsip

Arsip mempunyai
peranan yang sangat
penting dalam kelancaran
suatu kegiatan, oleh sebab
itu perlu diatur atau
ditentukan prosedur atau
tata cara peminjamannya
baik untuk keperluan
internal maupun eksternal
organisasi. Pencatatan
tentang peminjaman arsip
hendaknya dilakukan
dengan menggunakan
formulir khusus yang
disebut bon pinjam atau
out-slip atau lembar
peminjaman arsip.

Peminjaman arsip adalah keluarnya arsip dari file karena dipinjam baik oleh atasan sendiri, teman seunit kerja, ataupun oleh kolega sekerja dari unit kerja lain dalam organisasi. ${ }^{19}$ Karena arsip tersebut dipinjam sehingga tidak berada pada tempatnya, maka perlu adanya pencatatan supaya petugas arsip dapat mengetahui di mana arsipnya berada, siapa yang menggunakan, kapan dipinjam dan kapan harus dikembalikan.

Anjuran terhadap pencatatan ini juga tertulis dalam Al-Qur'an:

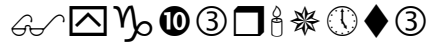

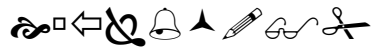

$$
\begin{aligned}
& \text { सेत्राव }
\end{aligned}
$$

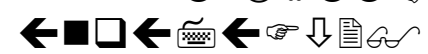

圓 Gor

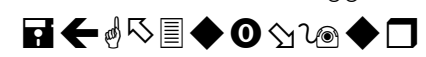

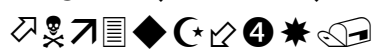

준.

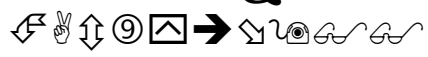

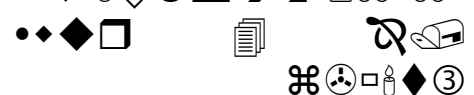

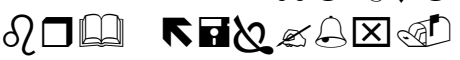

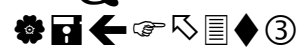
G $\triangle(\dot{0} \cdot$ ・圈

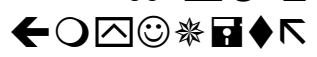

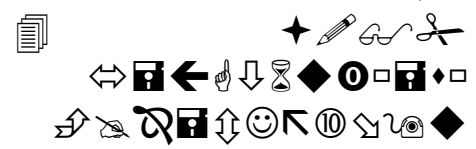

8d की की को 


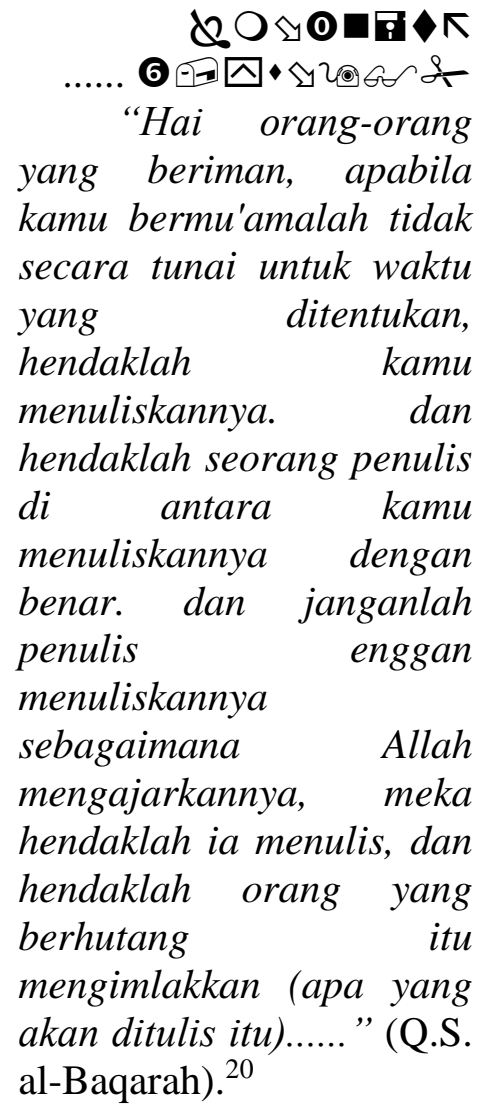

Dari Ibnu 'Abbas ra Rasulullah SAW bersabda:

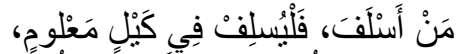

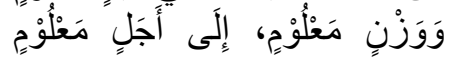

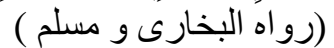
"Barang siapa yang meminjamkan sesuatu, maka hendaklah ia melakukannya dengan takaran timbangan yang disepakati sampai batas waktu yang ditentukan" (HR. Bukhari dan Muslim) $)^{21}$

Sedarmayanti mengemukakan lembar peminjaman arsip harus diisi rangkap 3 dengan fungsi
${ }^{20}$ Departemen Agama RI, Op. Cit, h. 48

21 'Abdullah Bin Muhammad Bin 'Abdurrahman Bin Ishaq Alu Syaikh, Tafsir Ibnu Katsir, Jilid 1, (Bogor: Pustaka Imam Syafi'i), 2004, h. 561 masing-masing yaitu sebagai berikut: 22

1) Lembar peminjaman arsip I (putih). Disimpan oleh penyimpan arsip berdasarkan tanggal pengembalian arsip, berfungsi sebagai bukti peminjaman.

2) Lembar peminjaman arsip II (hijau). Oleh penyimpan arsip diletakkan ditempat arsip yang dipinjam, berfungsi sebagai arsip yang dipinjam.

3) Lembar peminjaman arsip III (biru). Disertakan pada peminjam.

Dengan adanya lembar peminjaman arsip ini, pada saat adanya peminjaman arsip maka seorang arsiparis tidak perlu lagi mencari-cari arsip yang diperlukan oleh peminjam arsip, dan arsiparis segera mengetahui di mana letak arsip yang diperlukan itu berada.

c. Penemuan kembali arsip

Penemuan kembali arsip dapat dilakukan baik secara manual ataupun secara mekanik. Penemuan kembali secara manual berarti penemuan kembali dilakukan melalui kemampuan manusia tanpa menggunakan tenaga mesin. Sedangkan penemuan kembali dengan mekanik lebih banyak untuk menunjukkan lokasi

${ }^{22}$ Sedarmayanti, Dasar-dasar Pengetahuan tentang Manajemen Perkantoran Suatu Pengantar, Cet. 3, (Bandung: Mandar Maju), 2009, h. 202 
penyimpanan arsip melalui sarana elektronik (komputer).

Arsip yang ada tidak boleh disimpan sembarangan, arsip harus disimpan menggunakan sistem pengelolaan arsip yang baik dan benar sehingga arsip tersebut dapat dengan mudah ditemukan kembali dengan cepat, tepat pada waktu dibutuhkan. Agar penemuan kembali arsip dapat terlaksana dengan baik, maka beberapa syarat yang harus dilakukan adalah: ${ }^{23}$

1) Kebutuhan pemakai arsip atau surat harus diteliti dahulu dan sistemnya harus mudah diingat.

2) Harus didasarkan atas kegiatan nyata instansi yang bersangkutan, maka disusunlah kata tangkap atau indeks sebagai tanda pengenal.

3) Sistem penemuan kembali arsip harus logis, konsisten dan mudah diingat.

4) Sistem penemuan harus didukung oleh peralatan dan perlengkapan.

5) Selanjutnya sistem penemuan harus didukung oleh personil yang terlatih dan harus mempunyai daya tangkap yang

23 Hadi Abu Bakar, Pola Kearsipan Modern Sistem Kartu Kendali, (Jakarta: Cahaya Aksara), 1990, h. 74-75 tinggi, cepat, tekun,

suka bekerja,

senang bekerja

secara detail

tentang informasi.

Beberapa faktor
penunjang dan perlu
diperhatikan atau dipenuhi
dalam rangka memudahkan
dalam penemuan arsip adalah
sebagai berikut: ${ }^{24}$

1) Melakukan

kegiatan

menghimpun,

mengklasifikasi,

menyusun,

menyimpan dan

memlihara arsip

berdasarkan sistem

yang berlaku baik arsip yang bersifat kedinasan ataupun arsip pribadi pimpinan.

2) Dalam

menciptakan suatu sistem

penyimpanan arsip yang baik hendaknya

diperhatikan atau dipenuhi beberapa faktor penunjang, antara lain:

a) Kesedrahanan.

b) Ketepatan menyimpan arsip.

c) Memenuhi persyaratan ekonomis.

d) Menjamin keamanan.

e) Penempatan arsip.

${ }^{24}$ Sedarmayanti, Op.Cit, h. 204-205 
f) Sistem yang digunakan harus fleksibel.

g) Memahami pengetahuan di bidang kearsipan.

3) Unit arsip perlu menyelenggarakan penggandaan dan melayani peminjaman arsip dengan sebaikbaiknya.

4) Mencatat dan menyimpan pidato serta peristiwa yang terjadi setiap hari, lengkap dengan tanggal kejadiannya, agar dapat dijadikan alat bantu untuk menemukan atau mempertimbangka n kembali bila sewaktu-waktu diperlukan.

5) Mengadakan

pengontrolan arsip secara periodik agar dapat memahami seluruh media informasi yang ada dan mengajukan saran untuk mengadakan penyusutan serta pemusnahan bila perlu.

d. Pemeliharaan dan Pengamanan Arsip

1) Pemeliharaan Arsip

Pemeliharaan arsip adalah kegiatan membersihkan arsip secara rutin untuk mencegah kerusakan akibat beberapa sebab. Pemeliharaan arsip secara fisik dapat dilakukan melalui beberapa cara sebagai berikut: ${ }^{25}$

a) Pengaturan Ruangan Ruang

penyimpanan arsip harus dijaga agar tetap kering (temperatur ideal antara $\quad 60^{\circ}-75^{\circ} \mathrm{F}$, dengan kelembaban 50-60\%), terang (terkena sinar matahari tidak langsung), mempunyai ventilasi yang merata, dan terhindar dari kemungkinan serangan api, air, serangga dan sebgainya.

b) Tempat Penyimpanan Arsip Hendaknya

diatur secara renggang, agar ada udara di antara berkas yang disimpan. Tingkat kelembaban yang diinginkan perlu diketahui.

c) Penggunaan Bahanbahan Pencegah Rusaknya Arsip

Salah satu caranya adalah meletakkan kapur barus di tempat penyimpanan, atau

${ }^{25}$ Basir Barthos, Manajemen Kearsipan untuk Lembaga Negara, Swasta dan Perguruan Tinggi, (Jakarta: Bumi Aksara), 2009, h. 56 
mengadakan

penyemprotan

dengan bahan kimia

secara berkala.

d) Larangan-larangan

Perlu dibuat

peraturan yang

harhus dilaksanakan, antara lain: dilarang membawa dan/atau makan di tempat penyimpanan arsip, serta dalam ruangan penyimpanan arsip dilarang merokok (karena percikan api dapat menimbulkan bahaya kebakaran).

e) Kebersihan

Arsip harus selalu dibersihkan dan dijaga dari noda karat dan lain-lain.

2) Pengamanan arsip

Pengamanan arsip adalah menjaga arsip dari kehilangan maupun dari kerusakan. Secara fisik semua arsip harus diamankan dari segi kerusakan. Kerusakan arsip dapat terjadi karena faktor internal dan faktor eksternal. ${ }^{26}$

a) Faktor Internal, dapat berupa kualitas kertas, tinta, bahan perekat yang bersentuhan dengan kertas.

b) Faktor Eksternal, berupa lingkugan, sinar matahari, debu, serangan dari kutu dan sejenisnya, dan

26 Ibnu Syamsi (b), Pengambilan Keputusan dan Sistem Informasi, Ed. 2, Cet. 3, (Jakarta: PT. Bumi Aksara), 2007, h. 13-131

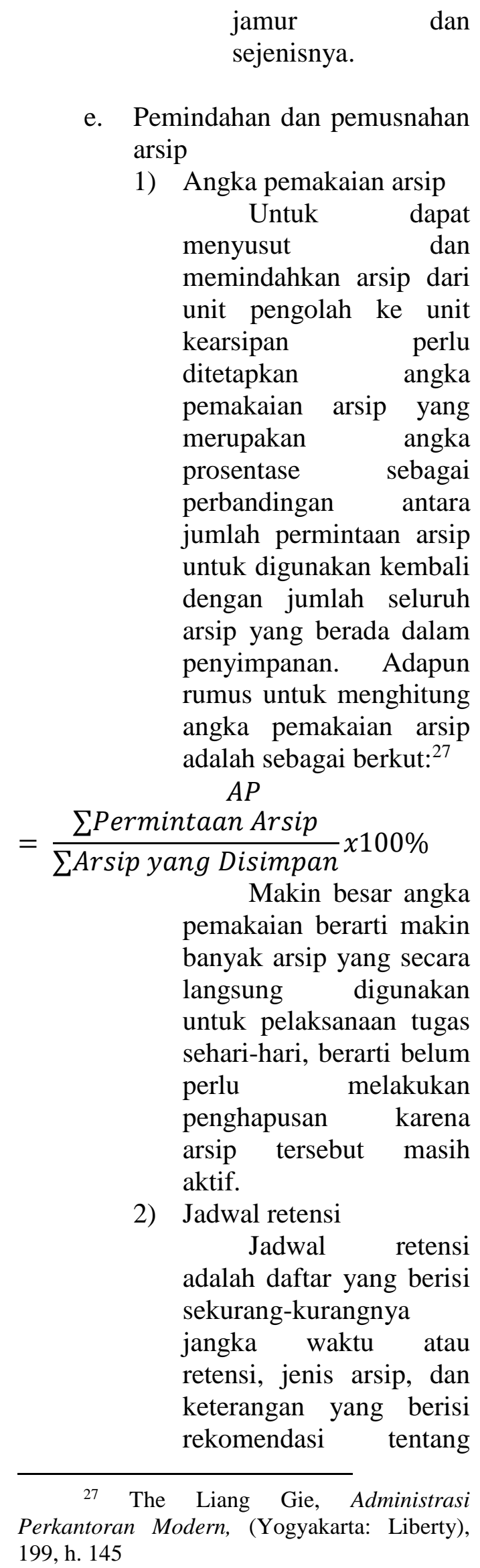

jamur dan

. Pemindahan dan pemusnahan arsip

1) Angka pemakaian arsip menyusut dan memindahkan arsip dari unit pengolah ke unit kearsipan perlu ditetapkan angka pemakaian arsip yang merupakan angka prosentase sebagai perbandingan antara untuk digunakan kembali dengan jumlah seluruh arsip yang berada dalam penyimpanan. Adapun rumus untuk menghitung angka pemakaian arsip dalah sebagai berkut: ${ }^{27}$ Makin besar angka pemakaian berarti makin banyak arsip yang secara langsung digunakan sehari-hari, berarti belum perlu melakukan penghapusan karena arsip tersebut masih aktif. adalah daftar yang berisi sekurang-kurangnya jangka waktu atau retensi, jenis arsip, dan keterangan yang berisi rekomendasi tentang 199, h. 145 
penetapan suatu jenis arsip dimusnahkan, dinilai kembali, permanenkan yang dipergunakan sebagai pedoman penyusutan dan penyelamatan arsip. $^{28}$ Dengan demikian jadwal retensi merupakan suatu daftar yang menunjukkan:

a) Lamanya masingmasing arsip disimpan pada file active (satuan kerja), sebelum dipindahkan ke pusat penyimpanan arsip (file in ative).

b) Jangka waktu penyimpanan masing-masing atau sekelompok arsip dimusnahkan ataupun dipindahkan ke Arsip Nasional.

Penentuan jangka waktu penyimpanan arsip (retensi arsip) ditentukan atas dasar nilai kegunaan tiap-tiap berkas. Untuk menjaga obyektivitas dalam menentukan nilai kegunaan tersebut, jadwal retensi arsip disusun oleh panitia yang terdiri dari pejabat yangbenar-benar memahami kearsipan, fungsi dan kegiatan kantor atau organisasinya masing-masing. ${ }^{29}$

Jadi, arsip yang dianggap sudah tidak diperlukan lagi tidak bisa dimusnahkan begitu saja akan tetapi harus merujuk pada jadwal retensi yang telah ditetapkan.

3) Pemindahan arsip adalah Pemindahan arsip memindahkan arsip-arsip dari aktif kepada in-aktif karena jarang sekali dipergunakan dalam kegiatan sehari-hari. Pemindahan arsip dapat juga berarti kegiatan memindahkan arsip-arsip yang telah mencapai jangka waktu tertentu ke tempat lain sehingga filling cabinet yang semula dipakai dalam pelaksanaan pekerjaan sehari-hari dapat dipergunakan untuk menyimpan arsip-arsip baru. ${ }^{30}$

4) Pemusnahan arsip

$$
\text { Pemusnahan arsip }
$$
adalah tindakan atau kegiatan menghancurkan secara fisik arsip yang sudah berakhir fungsinya, serta yang tidak memiliki nilai guna. Penghancuran tersebut harus dilakukan secara total, yaitu dengan cara dibakar habis, dicacah atau dengan cara lain sehingga tidak lagi dikenal baik isi maupun bentuknya. ${ }^{31}$

Tujuan

pemusnahan arsip adalah untuk efisiensi dan efektivitas kerja, serta

${ }^{31}$ Durotul Yatimah, Op.Cit, h. 214 
penyelamatan informasi arsip itu sendiri dari pihak-pihak yang tidak berhak untuk mengetahuinya. ${ }^{32}$ Arsip-arsip yang sudah tidak berguna lagi, perlu dimusnahkan untuk memberi kemungkinan bagi tersedianya tempat penyimpanan dan pemeliharaan yang lebih baik terhadap arsip-arsip yang mempunyai nilai guna. Oleh sebab itu, maka pemusnahan arsip harus dilakukan dengan prosedur yang benar. Hal ini sebagaimana yang dijelaskan dalam Pasal 52 ayat (1) UndangUndang Nomor 43 tahun 2009 tentang kearsipan, bahwa: "Setiap lembaga negara dan lembaga yang terkena kewajiban berdasarkan UndangUndang ini dilarang melaksanakan

pemusnahan arsip tanpa prosedur yang benar". ${ }^{33}$

Pemusnahan arsip dapat dilakukan dengan beberapa cara yaitu pembakaran, pencacahan, pemusnahan dan penghancuran.

Sedangkan prosedur pemusnahan arsip pada umumnya terdiri dari seleksi, pembuatan berita acara pemusnahan dan

32 Peraturan Kepala Arsip Nasional Republik Indonesia Nomor 25 Tahun 2012, Op. Cit, h. 1

33 Undang-Undang Nomor 43 Tahun 2009, h. 37 pelaksanaan pemusnahan arsip dengan saksi-saksi. Sebagaimana

disebutkan pada Pasal 3 Peraturan Kepala Arsip Nasional Republik Indonesia Nomor 25 tahun 2012 bahwa pemusnahan arsip dilaksanakan berdasarkan: a) Prinsip pemusnahan arsip, b) kriteria arsip yang dimusnahkan, dan c) pelaksana pemusnahan arsip. $^{34}$

4. Faktor penghambat dan pendukung dalam penataan arsip

Dalam pelaksanaan penataan arsip, arsiparis atau pengelola arsip akan menemukan faktor-faktor yang dapat dan mendukung proses penataan arsip tersebut. Di antara faktor-faktor yang dapat menghambat antara lain:

a. Hambatan dari unsurusnur input kearsipan seperti data dan informasi yang tidak berkualitas, bahan instrinsik data seperti kertas, film, disket, tinta yang tidak standar, peralatan yang tidak lengkap, jumlahnya kurang, keadaannya tidak baik (rusak), keuangan organisasi minim untuk belanja bidang kearsipan, dan sumber daya manusia yang tidak kompeten.

b. Hambatan proses kearsipan yaitu penciptaan naskah, pendistribusian,

34 Peraturan Kepala Arsip Nasional Republik Indonesia Nomor 25 Tahun 2012, Loc. Cit, h. 6 
penggunaan,

pemeliharaan,

penyimpanan dan penyusutan arsip tidak dapat dilaksanakan dengan baik dan tertib, serta tidak sesuai dengan prosedur kearsipan yang benar.

c. Output sistem kearsipan yaitu arispnya tidak memenuhi ciri-ciri arsip yang baik. Di mana arsipnya tidak tersimpan secara sistematis, sehingga menyulitkan penyimpanan dan penemuan kembali arsip saat diperlukan.

d. Kelemahan fungsi-fungsi manajemen kearsipan dan pelaksanannya seperti perencanaan kearsipan yang salah, pembagian kerja yang tidak adil, serta tidak ada hubungan kerja yang efektif secara horizontal dan vertikal antara pegawai dan pejabat yang bertanggungjawab terhadap sistem kearsipan, perencanaan dan pelaksanaan manajemen sumber daya manusia di bidang kearsipan yang buruk, lemahnya pemberian pembinaan dan motivasi terhadap pegawai arsip, dan pengawasan kearsipan yang tidak efektif. ${ }^{35}$

Kendala-kendala tersbut merupakan permasalahan yang dapat menghambat keefektifan penataan arsip. Oleh karena itu, arsiparis harus tanggap terhadap permasalahanKearsipan, (Malang: Dioma), 2006, h. 32 permasalahan yang terjadi dalam penataan arsip.

Sedangkan faktor-faktor yang dapat mendukung dalam penataan arsip, antara lain:

a. Penggunaan sistem penyimpanan yang tepat.

Sistem pemberkasan adalah suatu rangkaian tata cara yang teratur menurut suatu pedoman tertentu untuk menyusun atau menyimpan warkat-warkat sehingga apabila diperlukan dapat ditemukan kembali dengan cepat.

b. Fasilitas kearsipan memenuhi syarat

c. Petugas kearsipan yang memenuhi syarat.

Syarat-syarat

petugas tata usaha pada umunya adalah:

a. Memiliki pengetahuan di bidang pengetahuan umum, terutama yang menyangkut masalah surat menyurat dan arsip.

b. Pengetahuan tentang seluk-beluk

instansinya yakni, organisasi, tugastugasnya dan pejabatnya.

c. Pengetahuan khusus tentang kearsipan.

d. Berkepribadian, yakni memiliki ketekunan, kesabaran, ketelitian, kerapihan, kecekatan, kejujuran serta loyal dan dapat menyimpan rahasia organisasi. ${ }^{36}$

36 Suparjati, dkk, Tata Usaha dan Kearsipan, (Yogyakarta: Kansisus), 2004, h. 78 
Berdasarkan

pendapat para ahli di atas, maka dapat disimpulkan bahwa dalam kegiatan penataan arsip yang ditopang dengan sistem penataan arsip yang tepat, fasilitas kearsipan yang memadai, serta ruang penyimpanan arsip yang baik. Selain itu faktor penunjang yang paling penting adalah sumber daya manusianya. Sebagaimana Sabda Rasulullah SAW:

عن أبى هريرة رضي الله عنه قال:

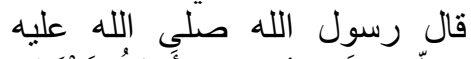

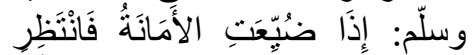

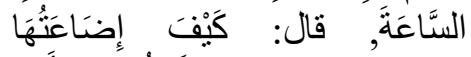

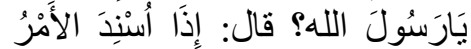

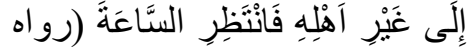

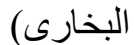

"Dari Abu Hurairah r.a ia berkata, Rasulullah S.a.w bersabda: Jika amanah telah hilang (sudah tidak dipegang lagi dengan teguh), maka tunggulah saat kehancurannya. Ia bertanya: Ya Rasul, bagaimana orang menghilangkan amanah itu? Rasul menjawab: (Yaitu) apabila suatu urusan (amanah) diserahkan kepada orang yang bukan ahlinya, maka tunggulah saat kehancurannya". (HR. Bukhari)

Oleh karena itu, agar pegawai kearsipan dapat memberikan pelayanan yang baik maka pegawai kearsipan perlu mendapatkan pelatihan dan penataran tentang kearsipan.

\section{METODE PENETILITIAN}

Jenis penelitian ini adalah kualitatif dengan menggunakan pendekatan studi kasus. Penelitian ini dilaksanakan di Madrasah Aliyah Negeri 1 Pekanbaru pada tanggal 26 September sampai dengan 20 November 2013. Adapun informan dalam penelitian ini berjumlah 3 orang yang terdiri dari: kapala tata usaha, 1 orang staff tata usahan dan 1 orang wakil kepala MAN 1 Pekanbaru. Di mana kepala tata usaha dan staff tata usaha sebagai sumber data primer, dan wakil kepala madrasah sebagai sumber data skunder. Pengumpulan data dilakukan dengan wawancara, observasi dan dokumentasi. Dalam pengujian kredibelitas data digunakan triangulasi data yakni triangluasi sumber, triangulasi metode, dan triangulasi teori. Data dalam penelitian ini dianalisis dengan menggunakan model Miles dan Huberman yakni, data reduction (Reduksi data, data dispalay (Model data), dan consclusion drawing/verification (Penarikan/Verifikasi kesimpulan)

\section{PEMBAHASAN}

1. Penataan Arsip

a. Penyimpanan terhadap arsip Berdasarkan hasil wawancara dan observasi yang penulis lakukan kepada para responden mengenai penyimpanan terhadap arsip di Madrasah Aliyah Negeri 1 Pekanbaru, para pegawai pengelola arsip telah melakukan penyimpanan terhadap arsip, dimana penyimpanan yang digunakan 
adalah sistem pokok masalah merujuk Keputusan Menteri Agama Nomor 44 tahun 2010 tentang pola klasifikasi arsip di lingkungan Kementerian Agama. Jadi, instansi atau Lembaga yang berada di lingkungan Kementerian Agama harus mengikuti KMA Nomor 44 Tahun 2010 ini.

b. Pencatatan terhadap peminjaman arsip

Berdasarkan hasil

wawancara dan observasi yang penulis lakukan kepada para responden maka dapat ketahui bahwa dalam hal pencatatan terhadap peminjaman arsip di Madrasah Aliyah Negeri 1 Pekanbaru belum melakukan pencatatan sebagaimana mestinya. Peminjaman arsip di Madrasah Aliyah Negeri 1 Pekanbaru dilakukan secara sederhana saja, peminjam arsip langsung datang ke pegawai pengelola arsip. Peminjaman juga tidak menggunakan syarat tertentu hanya menggunakan asas kepercayaan pegawai kepada peminjam dan tidak ada batas waktu peminjaman terhadap arsip.

Sistem peminjaman arsip di Madarasah Aliyah Negeri 1 Pekanbaru belum sesuai dengan teori yang ada. Hal ini dibuktikan dengan belum diberlakukannya pedoman dan syarat khusus peminjaman arsip yang harus menggunakan lembar peminjaman arsip yang dibuat rangkap tiga yang berfungsi sebagai bukti peminjaman, sebagai pengganti arsip yang dipinjam dan disertakan pada peminjam.

c. Pengecekan kembali terhadap arsip

Berdasarkan hasil wawancara yang penulis lakukan dengan responden mengenai pengecekan kembali terhadap arsip dapat disimpulkan bahwa proses pengecekan kembali arsip yang dipinjam dan yang telah dikembalikan di Madrasah Aliyah Negeri 1 Pekanbaru belum berjalan dengan baik, ini dikarenakan pegawai tata usaha hanya melakukan pengecekan tarhadap arsip ketika adanya peminjaman arsip yang sama yang dilakukan oleh pihak lain.

d. Penemuan kembali arsip

Berdasarkan hasil wawancara yang penulis lakukan kepada para responden tentang penemuan kembali arsip di Madrasah Aliyah Negeri 1 Peknbaru dapat dismpulkan bahwa penemuan kembali arsip di Madrasah Aliyah Negeri 1 Peknbaru dengan menggunakan cara manual dan elektronik atau komputerisasi. Cara elektronik atau komputerisasi digunakan apabila ingin mencari data yang berhubungan dengan siswa seperti nilai yang berada bagian puskom.

Akan tetapi dalam penemuan kembali arsip para pengelola arsip di Madrasah Aliyah Negeri 1 Pekanbaru belum menggunakan angka 
kecermatan arsip yang merupakan angka perbandingan antara jumlah arsip yang tidak diketemukan pada waktu yang diperlukan dengan arsip yang ditemukan yang dinyatakan dengan prosentase. Dalam hal ini sebaiknya para pengelola arsip di Madrsah Aliyah Negeri 1 Pekanbaru sebaiknya menggunakan angka kecermatan arsip sehingga dapat dinilai sejauh mana tingkat keberhasilan dari sistem yang digunakan.

e. Pemeliharaan dan pengamanan arsip Berdasarkan hasil wawancara kepada para responden dapat disimpulkan bahwa pemeliharaan dan pengamanan arsip di Madrasah Aliyah Negeri 1 Pekanbaru sudah dilakukan oleh para pengelola arsip, hal ini dibuktikan dari hasil observasi penulis di mana arsip-arsip yang ada di Madrasah Aliyah Negeri 1 Pekanbaru disimpan pada tempat penyimpanan arsip seperti map, ordner, dan lemari arsip. Kemudian membersihkan almari arsip yang ada di dalamnya dari debu. Namun, demikian penulis memandang para pengelola arsip Madrasah Aliyah Negeri 1 Pekanbaru harus lebih meningkatkan lagi pemeliharaan dan pengamanan arsip demi keberlangsungan keberadaan arsip itu sendiri.

f. Pemindahan dan pemusanahan arsip
Berdasarkan

pengamatan dan wawancara penulis para pengelola arsip Madrasah Aliyah Negeri 1 Pekanbaru sudah melakukan pemindahan terhadap arsip yang sudah berkuarang masa penggunaannya ke ruangan khusus, akan tetapi sampai saat ini belum melakukan pemusnahan terhadap arsip. Namun, dalam pemusnahan arsip cara yang akan digunakan adalah dengan membakar arsip-arsip yang tersebut.

Mengenai pembuatan jadwal retensi arsip belum dilakukan karena belum adanya arsip yang akan dimusnahkan, seharusnya walaupun belum ada arsip yang akan dimusnahkan jadwal retensi arsip itu harus ada, karna jadwal retensi arsip merupakan waktu di mana arsip itu sudah habis masa pakai dan nilainya. .

Dari hasil analisis data wawancara kepada informan penelitian tentang implementasi sistem penataan arsip di Madrasah Aliyah Negeri 1 Pekanbaru, maka dapat disimpulkan bahwa penataan arsip secara umum belum baik karna ada aspek yang tidak dilaksanakan pada saat penataan arsip.

2. Faktor penghambat dan pendukung

a. Faktor penghambat:

Dari hasil wawancara yang penulis lakukan kepada responden terkait dengan sumber daya manusia ini dapat diketahui bahwa kepala tata usaha 
merupakan lulusan D3

Akademi Sekrteris Persada

Bunda, kemudian lamanya menjabat sebagai kepala tata usaha yang sudah mencapai 3 tahun, serta staff tata usaha yang merupakan lulusan SMA dan sudah bekerja di bidang pengelolaan arsip MAN 1 Pekanbaru selama 12 tahun. Dari latar belakang pendidikan ini akhirnya berpengaruh kepada pemahaman pegawai itu sendiri dalam impelementasi sistem penataan arsip di Madrasah Aliyah Negeri 1 Pekanbaru.

b. Faktor pendukung:

1) Fasilitas/sarana prasarana yang sudah cukup mendukung dalam penataan arsip.

Sarana prasarana di Madrasah Aliyah Negeri 1 Pekanbaru megalami kendala tersendiri, ini disebabkan banyaknya arsip yang menumpuk karena belum dilakukan pemusnahan. Jika dibiarkan terus menerus akan menumbulkan keengganan pegawai untuk bekerja lebih giat lagi.

$\begin{array}{lr}\text { Adapun } & \text { sarana } \\ \text { prasarana } & \text { kearsipan } \\ \text { yang di } & \text { Madrasah } \\ \text { Aliyah Negeri 1 } & \text { Negari } \\ \text { Pekanbaru antara lain: }\end{array}$

a) Tempat penyimpnan arsip dari segi keamanan b) Ruangan, almari arsip dan rak arsip, dan sebagainya

c) Sistem komputerisasi.

2) Adanya pengawasan yang dilakukan oleh kepala mdarasah dalam imepelementasi sistem penataan arsip

Pengawasan yang dilakukan kepala madrasah bertujuan agar impelentasi sistem penataan arsip di MAN 1 Pekanbaru ini berjalan dengan baik seagaimana mestinya.

3) Terciptanya

komunikasi dan kerja sama yang baik antara pengelola arsip dengan kepala madrasah.

Dalam penataan arsip di Madrasah Aliyah Negeri 1 Pekanbaru kerja sama ini juga diterapkan, di mana bentuk kerja sama yang dilakukan antara lain:
a) Kepala madrasah mengusahakan pengadaan sarana prasarana yang diperlukan dalam penataan arsip.
b) Kepala madarasah ikut membantu para pegawai dalam pengelolaan arsip.

\section{PENUTUP}

A. Kesimpulan

Setelah semua tahap penelitian dilakukan, mulai dari pembuatan proposal 
penelitian, kemudian pengkajian teori, penyusunan instrumen penelitian sampai dengan pengumpulan data, pengolahan dan analisis data. Pada akhirnya peneliti dapat menyimpulkan bahwa:

1. Impelementasi sistem penataan arsip di Madrasah Aliyah Negeri 1 Pekanbaru yakni:

a. Sudah melakukan penyimpanan terhadap arsip dengan menggunakan salah satu sistem yaitu sistem nomor.

b. Belum melakukan pencatatan terhadap peminjaman arsip, serta belum adanya kartu peminjaman arsip.

c. Sudah melakukan pengecekan terhadap peminjaman dan pengembalian arsip, hanya saja pengecekan dilakukan ketika adanya peminjaman arsip.

d. Penemuan kembali terhadap arsip saat diperlukan menggunakan cara manual dan elektronik (komputerisasi) dengan waktu 5-10 menit.

e. Sudah melakukan pemeliharan dan pengamanan arsip, dengan cara memasukkan arsip ke tempat penyimpanan arsip dan membersihkan tempat penyimpanan dari debu.

f. Sudah melakukan pemindahan terhadap arsip, hanya saja belum melakukan pemusnahan dan pembuatan jadwal retensi arsip.

2. Faktor-faktor penghambat dan pendukung:

a. Faktor penghambat:

Latar belakang pendidikan pegawai pengelola arsip atau sumber daya manusia yaitu, kepala tata usaha adalah lulusan D3 Akademi Sekretaris Bunda Persada, kemudian staff tata usaha lulusan SMA.

b. Faktor pendukung:

a) Fasilitas/sarana prasarana yang sudah cukup mendukung dalam penataan arsip.

b) Adanya pengawasan yang dilakukan oleh kepala mdarasah dalam imepelementasi sistem penataan arsip

c) Terciptanya komunikasi dan kerja sama yang baik antara pengelola arsip dengan kepala madrasah.

B. Saran

Berdasarkan $\quad$ hasil
penelitian yang telah
disimpulkan di atas dan dalam
implemenatasi sistem penataan
arsip di Madrasah Aliyah
Negeri 1 Pekanbaru,


dikemukakan beberapa saran sebagai berikut:

1. Kepada para pegawai pengelola arsip (arsiparis), disarankan untuk mempelajari dan memahami manajemen kearsipan, sehingga senantiasa dapat melaksanakan tugasnya dalam menata arsip secara baik dan benar.

2. Dalam pelaksanaan penataan arsip harus melakukan pencatatan terhadap peminjaman arsip, menggunakan kartu setiap peminjaman arsip, melakukan pengecekan kembali terhadap peminjaman dan pengembalian arsip, menggunakan angka kecermatan dalam menemukan arsip, membuat jadwal retensi arsip sebelum arsip dimusnahkan dan melakukan pemusnahan terhadap arsip.

3. Kepada para pemegang kebijakan dalam pendidikan disarankan beberapa hal sebagai berikut:

a. Melakukan pemberdayaan pegawai pengelola arsip yang potensial dan mengikutsertakan dalam pelatihanpelatihan tentang kearsipan.

b. Meningkatkan komunikasi dan konsultasi dengan berbagai pihak; kepala madarasah, guru, karyawan madarasah lainnya.

c. Mengusahakan tersedianya sumber dana, sumber informasi dan sarana prasarana pendukung ketercapaian

implementasi sistem penataan arsip yang baik dan benar.

4. Dengan adanya beberapa keterbatasan dalam penelitian ini, kepada peneliti lain diharapkan untuk mengadakan penelitian sejenis lebih lanjut dengan mengambil wilayah penelitian yang lebih luas, sampel yang lebih banyak dan menggunakan rancangan penelitian yang lebih kompleks, melakukan penelitian pada tingkat pendidikan yang lebih tinggi seperti pada Universitas, sehingga dapat ditemukan hasil yang lebih optimal dan bisa digeneralisasikan pada wilayah yang lebih luas.

\section{REFERENSI}

'Abdullah Bin Muhammad Bin 'Abdurrahman Bin Ishaq Alu Syaikh, Tafsir Ibnu Katsir, Jilid 1, (Bogor: Pustaka Imam Syafi'i), 2004.

Agus Sugiarto dan Teguh Wahyono, Manajemen Kearsipan Modern, (Yogyakarta: Gava Media), 2005. 
Badri Munir Sukoco, Administrasi Perkantoran Modern, (Surabaya: Erlangga), 2007.

Basir Barthos, Manajemen Kearsipan untuk Lembaga Negara, Swasta dan Perguruan Tinggi, (Jakarta: Bumi Aksara), 2009.

Departemen Agama Republik Indonesia, Al-Qur'an dan Terjemahan, (Jakarta: Indiva), 2009.

Durotul Yatimah, Pengembangan Sumber Daya Manusia: Kesekretariatan Modern dan Administrasi Perkantoran, (Bandung: Pustaka Setia), 2009.

Edy Roesdiono, Mengelola Dokumen dengan Sistem Abjad, (Pekanbaru: Direktorat Jenderal Pendidikan Dasar dan Menengah Departemen Pendikan Nasinoal), 2003.

\section{Mengelola Dokumen}

dengan Sistem Pokok Masalah, (Pekanbaru: Direktorat Jenderal Pendidikan Dasar dan Menengah Departemen Pendikan Nasinoal), 2003.

\section{dengan, $\begin{gathered}\text { Mengelola Dokumen } \\ \text { Sistem }\end{gathered}$ (Pekanbaru: Direktorat Jenderal Pendidikan Dasar dan Menengah Departemen Pendikan Nasinoal), 2004.}

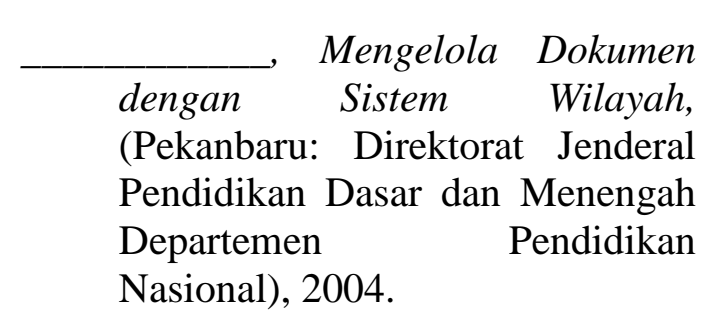

Hadi Abu Bakar, Pola Kearsipan Modern Sistem Kartu Kendali, (Jakarta: Cahaya Aksara), 1990.

Hayatur Rahmi, Pengelolaan Arsip Dinamis Aktif di Badan Kepegawaian Daerah Provinsi Jawa Barat, Vo. 1, No. 1, (eJurnal Mahasiswa Universitas Padjadjaran), 2012.

Ibnu Syamsi (a), Sistem dan Prosedur Kerja, (Jakarta: Bumi Aksara), 1994.

Ibnu Syamsi (b), Pengambilan Keputusan dan Sistem Informasi, Ed. 2, Cet. 3, (Jakarta: PT. Bumi Aksara), 2007.

Peraturan Kepala Arsip Nasional Republik Indonesia Nomor 25 Tahun 2012

Sedarmayanti, Dasar-dasar Pengetahuan tentang Manajemen Perkantoran Suatu Pengantar, Cet. 3, (Bandung: Mandar Maju), 2009.

Sri Endang R, dkk, Modul Mengelola dan Menjaga Sistem Kearsipan: Bidang Keahlian Bisnis dan Manajemen (Program Keahlian Administrasi Perkantoran) untuk SMK dan MAK, (Jakarta: Erlangga), 2009.

Suparjati, dkk, Tata Usaha dan Kearsipan, (Yogyakarta: Kansisus), 2004.

U. Saefullah, Manajemen Pendidikan Islam, (Bandung: CV. Pustaka Setia), 2012. 
Undang-Undang RI Nomor 43 Tahun 2009, Tentang Kearsipan.

Yohanes Suraja, Manajemen Kearsipan, (Malang: Dioma), 2006.

Zulkifli Amsyah, Manajemen Kearsipan, Cet. Ke-9 (Jakarta: PT. Gramedia Pustaka Utama), 2001. 